\title{
A METHODOLOGY FOR THE DEVELOPMENT OF HISTORICAL BUILDING ARCHETYPES FOR SEISMIC PERFORMANCE ASSESSMENT
}

\author{
${ }^{1}$ Eduardo Charters MORAIS, ${ }^{2}$ László G. VIGH, ${ }^{3}$ János KRÄHLING
}

\author{
Department of Structural Engineering, Faculty of Civil Engineering, Budapest University of \\ Technology and Economics, Mủegyetem rkp. 3, 1111 Budapest, Hungary \\ e-mail: 1eduardo.charters@epito.bme.hu, 2vigh.l.gergely@epito.bme.hu \\ ${ }^{3}$ krahling@eptort.bme.hu
}

Received 31 December 2016; accepted 8 September 2017

\begin{abstract}
The probabilistic estimation of the magnitude of historical earthquakes requires the analysis of actual building structures affected by those earthquakes. The analysis complicates because most of these buildings no longer exist or were greatly modified, present a great variety of features and the number of analysis for probabilistic assessment is high. As it is not practical to analyze all structures, an alternative is to use structural archetypes representing the affected buildings. This paper presents an approach to develop a quantitative framework for the generation of historical archetypes. The method is illustrated via the definition of a specific archetype for the study and assessment of the effects of the 1763 Komárom earthquake. The historical survey of Tata, Hungary, is assumed as representative of the region and one historical building is utilized to illustrate the archetypes evaluation process.
\end{abstract}

Keywords: Structural archetype development, 1763 Komárom earthquake, Historical architecture, Historical building survey, Probabilistic earthquake magnitude assessment

\section{Introduction}

The great majority of seismic events occurred long before the advent of modern seismology $\left(20^{\text {th }}\right.$ century onwards). Therefore, seismologists often engage in considerable efforts to study the macro-seismic effects of historical earthquakes in order to characterize the seismicity of a given region. This is particularly important in regions with low to moderate seismicity, as in Hungary, where the number of seismic records to perform seismic dynamic analysis of new buildings is scarce, as can be seen in [1]. The most common techniques used by seismologists, after the evaluation of the macroseismic effects, rely on the Modified Mercalli Intensity scale (MMI) to provide intensity 
point(s) [2], [3]. Afterwards, they use empirical relationships relating magnitude with either the epicentral intensity or radius to achieve the magnitude estimates. This process greatly simplifies the issue of the structural behavior of the buildings affected by the earthquake. An alternative approach considers the structural nonlinear behavior, relying on structure specific fragility functions, and uses the background of Probabilistic Seismic Hazard Analysis (PSHA) for magnitude estimation [4]. In turn, fragility functions can be achieved either by experimental laboratory tests or by analytical tools, with the Capacity Spectrum Method (CSM) [5] or Dynamic Structural Analysis (DSA) [6], [7], which require the structural modeling of the buildings damaged by the historical earthquake in study. This study is complicated by the fact that most of these buildings do not exist anymore, or were considerably modified, making them unsuited for analysis. An alternative solution is to create structural archetypes representing the affected building environment. Therefore, in order to create the structural archetypes, the framework must incorporate regular geometrical and mechanical properties so that the seismic behavior of the archetypes can be associated to that of the buildings affected by the earthquake.

The present paper focus on the development of structural archetypes for the estimation of the magnitude of the historical earthquake of Komárom, occurred in 1763. The method uses buildings of interest selected from the historical building survey of Tata [8] - due to the proximity and similar architecture - to create a numerical framework of geometrical parameters and indices [9], [10] providing the bounds in which the archetype is generated. In turn, the form of the archetypes is provided either by bibliography or abstraction from the historical analysis of the surveyed buildings. The use of the indices should guarantee the equivalence between the seismic behavior of archetypes and real buildings.

\section{Probabilistic magnitude estimation methodology}

A new method providing magnitude estimates based on the seismic damage analysis of historical buildings [4] (Fig. 1) triggers a considerable shift in the field of historical earthquake research, as the discussion is no longer prone just to the cooperation between seismologists and historians [11] but also to earthquake engineers and architect historians.

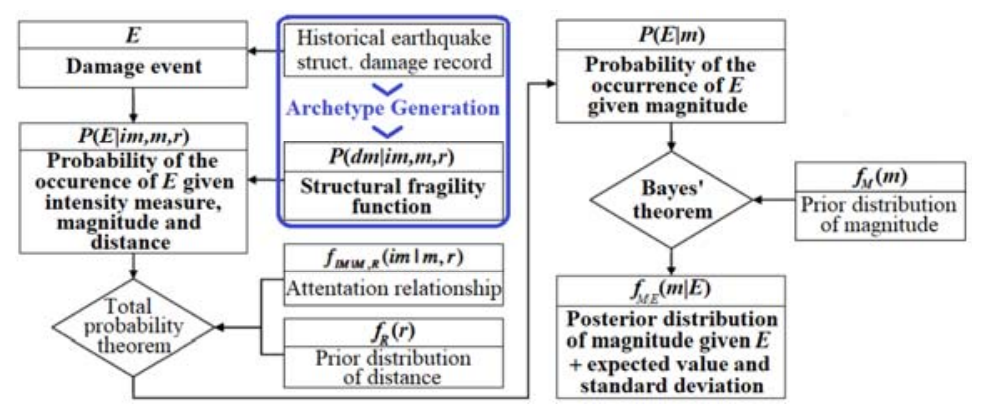

Fig. 1. Present scope in the flowchart of the magnitude estimation method, on the basis of [4] 
An application of the method for the 1763 Komárom earthquake, proposed and explored in [4] (Fig. 1), is illustrated here in order to highlight the relevance and aim of the historical archetypes. This application example is detailed in [12] and makes use of the processes developed in [13]. Despite the correct use of methodology, the reliability of the final magnitude estimates is still conditioned by uncertainties related to the model, strength parameters and to the quantification and relation of the building/damage pairs.

\subsection{Fragility functions}

The fragility functions $P\left(d m_{i} \mid i m, m, r\right)$ were generated with the help of a nonlinear spring model calibrated for the walls of an archetype (Fig. 2, left) and subjected to ground acceleration records. The algorithm was written for Incremental Dynamic Analysis (IDA), a DSA technique, for which the PGA is gradually scaled until the collapse of the structure (Fig. 2, center). This process enables the determination of the damage points associated with the damage states $d m_{1}$ to $d m_{4}$ [12], to which lognormal CDFs, or fragility functions (Fig. 2, right), are fitted. These are used in the magnitude estimation procedure (Fig. 1) to estimate the probability of a damaging event $P(E \mid i m, m, r)$ which is achieved by combining the fragilities with the number of buildings under damage states $n_{k}=\left[\begin{array}{llll}d m_{0} \ldots d m_{4}\end{array}\right]=\left[\begin{array}{lllll}105 & 44 & 42 & 35\end{array}\right]$, fractions of the total number of damaged structures [14], [15].
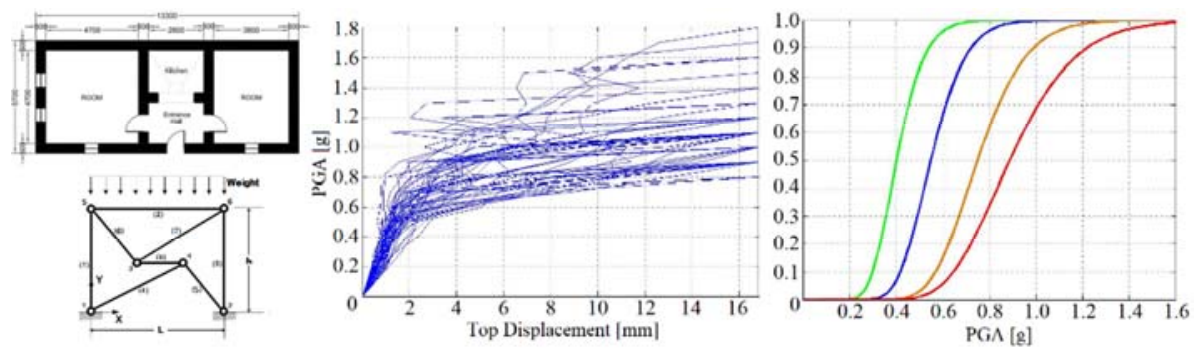

Fig. 2. Archetype 'A0' and structural model (left), IDA analysis (center) and respective fragility functions (right), on the basis of [13]

\subsection{Magnitude estimation}

The probability of the event given a magnitude $P(E \mid m)$ is calculated using the total probability theorem, by integrating the probability of the damaging event $E$, $P(E \mid i m, m, r)$, together with the attenuation relationship $\left(f_{i m \mid m, r}\right.$, Fig. 3, centre) [16] and distribution of distance $\left(f_{r}, F i g .3\right.$, left, with $\left.r_{u}=20 \mathrm{~km}\right)$. Afterwards the Bayes' theorem used a uniform prior distribution of magnitude $\left(f_{m}\right)$ to calculate the posterior distribution of magnitude and a magnitude expected value of 6.5. Even though, a key point in the methodology, before the calculation of the fragilities, is to input the historical earthquake structural damage record providing the number of structures of a given type under different damage states. In this case, a structural archetype of peasant house was 
arguably assumed, based on expert judgment. Although, archetype should also be endorsed by both the literature and historical sources, and the historical survey of the buildings of interest.
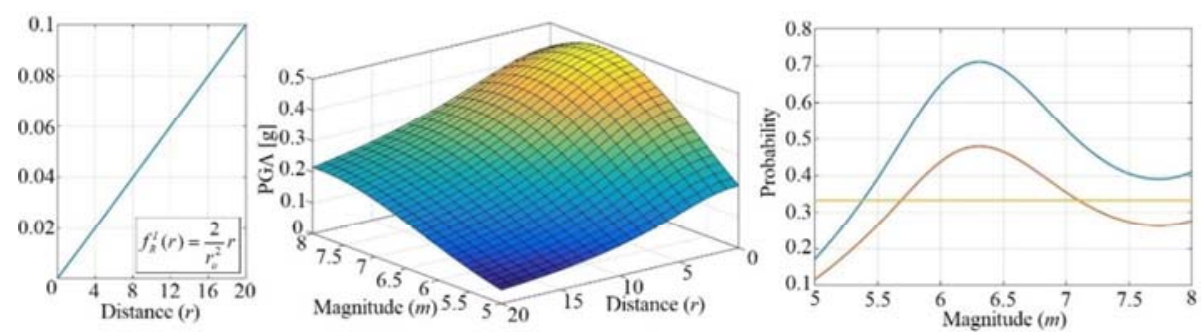

Fig. 3. Distance distribution (left), median PGAs (center) and magnitude PDF and CDF (right)

\section{Historical damage sources and magnitude estimates}

The 1763 seismic event, with epicenter near Komárom, was one of the strongest and most destructive in Hungarian history (Table I). It occurred before the instrumental era in seismology, 8 years after the 1755 Lisbon earthquake, when European institutions started regarding earthquakes as a natural hazard, rather than a product of sin, which rapidly led to the production of books [17], documents [18], depictions (Fig. 4) and oral descriptions.
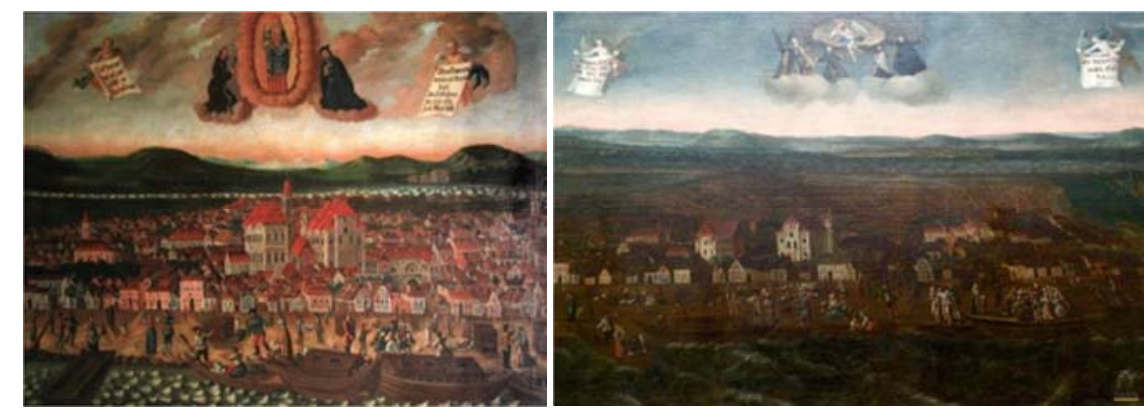

Fig. 4. Buildings affected by the 1763 Komárom earthquake: anonymous depiction (left), depiction by Karl Friedl ((right)

\subsection{Later sources and magnitude estimates}

The production of later sources related to the 1763 earthquake is both scientific and popular, edited into periodicals and books. The founding remark in seismology was written in Réthly's The Earthquakes of the Carpathian Basin [19] with antecedent in the $18^{\text {th }}$ century Dissertatio de Terrae Motibus Regni Hungariae, by János Grossinger [17] an eye-witness of the event. The work sourced the later characterization of the regional seismicity [14], [20]-[22]. The magnitude is currently estimated in between 5.7 [23]-[25] and 6.5 [15] (Table I). This gap is due to two different approaches: the first 
considers the work of Réthly [19], the other refers Szeidovitz works with primary sources and estimates of [2], [3] leading to estimate between 6.1 and 6.5 as it is shown in [11], [26]. As to the damage, contemporary sources refer to $91 \%$ of damaged buildings in the city of Komárom, in several degrees: 279 completely destroyed, 353 partially collapsed, 213 needed expensive repairs and 219 cheap repairs [14], [15].

Table I

Magnitude (M) estimations of the major seismic events occurred in Hungary [21]

\begin{tabular}{|c|c|c|c|c|c|c|c|}
\hline Local & Szombathely & Komárom & Mór & Jászberény & Kecsckemét & Eger & Dunaharaszti \\
\cline { 1 - 4 } \cline { 5 - 8 } Date & 456 & 1763 & 1811 & 1868 & 1911 & 1925 & 1956 \\
\cline { 1 - 4 } M & 6.6 & $5.7 \sim 6.5$ & 5.4 & 4.9 & 5.6 & 5.3 & 5.6 \\
\hline
\end{tabular}

\subsection{Historical sources and structural damage records}

Historical sources exist as official documents [18], depictions (Fig. 4), books [17] and newspaper articles [19]. The Consilium Locumtenentiale was ordered to evaluate the damage and quantify the repair costs in the region, resulting in a report entitled Acta Terrae Motus Anni 1763, in fascicles A to F (mainly letters). No. 10 of fascicle A focuses on the quantification of costs by city for four different building categories, as shown in Szeidovitz [3]. Religious buildings as churches, parochial houses and chapels compose the first category, castles, palaces and manors the second, public buildings, inns, mills and kilns the third, and taxpayers' houses the fourth. Additionally, Grossinger refers the most damaged buildings as two-story brick public, ecclesiastical or civil houses, rather than simpler and more flexible peasant houses [17].

The sources, regarding [4], lead us into a dichotomy in structural modeling: still existing affected monumental buildings may guarantee a reliable building/damage relation and are relatively well documented, but fall into modeling complexity and lack representativeness. In [27], initial steps were taken to analyze the church of Zsámbék, which has damage descriptions due to the 1763 earthquake. Another path [13] studies simpler and highly representative (in damage numbers) buildings (dwelling houses, mills, kilns, etc.), and low modeling complexity, but generalizes the building/damage relations of perhaps idealized buildings. This paper aims for the second path, although that generalization requires a methodology to generate building archetypes coherent with the historical sources.

\section{Archetype generation}

The main issue of this paper is how to define building types for DSA. Archetypes are defined as 'structures that fairly represent the range of configurations and properties of the building group of interest' [28]. The interest period is set here for the $18^{\text {th }}$ century or earlier. These buildings were built of earth, adobe, burnt clay or stone masonry, or even wood and the usual seismic resistant structural elements are masonry walls, arches, vaults and wooden frames. Historical buildings can be studied using true-to-form survey, general survey, historical plans, solely on expert opinion or from general 
bibliography, for instance [8], [29]. It is from this survey that the qualitative and quantitative analysis and comparison should arise, aiming for the development of a flexible, comprehensive and quantitative approach for generating of structural archetypes for DSA.

\subsection{Historical survey of Tata}

There is no broad historical building survey of the city of Komárom. Although, Tata holds regional similarities, in terms of architecture and construction techniques, and some of its historical building are surveyed [8] making it a candidate to source the archetypes generation process. From a list of 122 buildings gathered from historical monuments literature [30]-[32] matching the periodization criteria and having available plans [8], [30], 35 were selected (Table II). These buildings were organized by function categories and sub-categories (Fig. 5), being that the great majority (45\%) are dwellings.

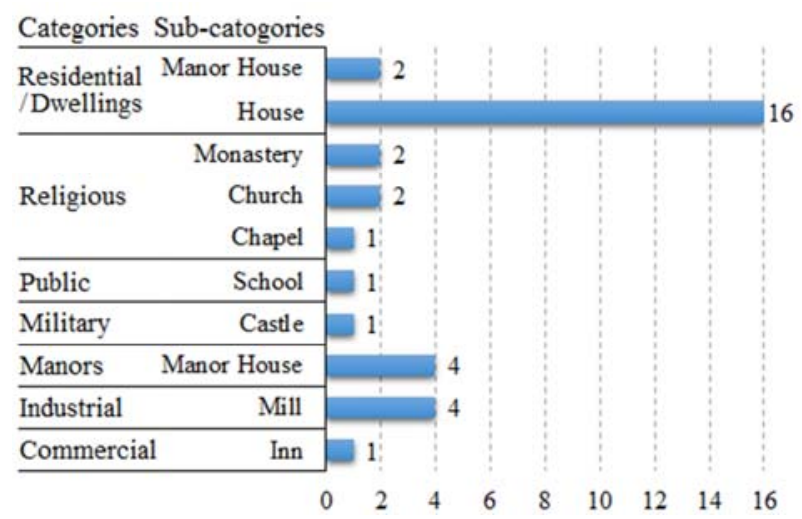

Fig. 5. Categories and sub-categories of the historical survey of Tata [8]

Additionally, their probable location was identified in the first military map (17631787, Fig. 6) [33], with the help of the survey plans and other city maps. The period of the buildings and intervention descriptions were cross-checked in sources leading to the identification of the buildings in the list and outwit the changes in the street names and urban network [8], [30]. In modern reticular structures, regularities are often associated with typical geometrical parameters as height, span, number of stories, plan area, crosssection dimension, etc. Historical buildings are usually low-rise and contain structural elements of relatively high mass and complexity as self-supporting walls, columns, arches and vaults, i.e. [34], and some difficulties may arise from both the qualitative and quantitative analyses, or by limitations of the surveying method. Therefore, besides the geometrical regularity, historical archetypes require the use of indices similar to those of the real buildings, in order to match their seismic behavior. 
Table II

Historical buildings selected from the survey of Tata (T1993) [8] and bibliography: G1959 [30], R1964 [31] and H2006 [32]. The shadowed cells indicate the availability of respective plans

\begin{tabular}{|c|c|c|c|c|c|c|}
\hline ID & Street name & No. & G1959 & R1964 & H2006 & T1993 \\
\hline 1 & & 9 & $\sqrt{ }$ & - & - & $\sqrt{ }$ \\
\hline 2 & Ady Endre & 11 & $\checkmark$ & $\checkmark$ & $\checkmark$ & $\checkmark$ \\
\hline 3 & & 22 & $\checkmark$ & $\checkmark$ & $\checkmark$ & $\checkmark$ \\
\hline 4 & & 1 & $\checkmark$ & $\checkmark$ & $\checkmark$ & - \\
\hline 5 & Alkotmány & 2 & $\sqrt{ }$ & - & $\checkmark$ & $\checkmark$ \\
\hline 6 & Alkotmany & 3 & $\checkmark$ & - & $\checkmark$ & $\sqrt{ }$ \\
\hline 7 & & 6 & $\sqrt{ }$ & $\checkmark$ & $\sqrt{ }$ & $\sqrt{ }$ \\
\hline 8 & Anoolkert & - & - & $\checkmark$ & - & $\checkmark$ \\
\hline 9 & Angolkert & - & $\checkmark$ & - & - & $\checkmark$ \\
\hline 10 & Bajcsy Zsilinszky & 24 & $\checkmark$ & - & - & $\sqrt{ }$ \\
\hline 11 & Bartók Béla & - & $\checkmark$ & - & $\checkmark$ & $\checkmark$ \\
\hline 12 & & 1 & - & $\checkmark$ & - & $\checkmark$ \\
\hline 13 & Bercsénvi & 1 & $\checkmark$ & $\sqrt{ }$ & $\checkmark$ & $\checkmark$ \\
\hline 14 & Bercseny1 & 7 & $\checkmark$ & $\checkmark$ & - & $\checkmark$ \\
\hline 15 & Fazekas & 4 & $\checkmark$ & - & - & $\checkmark$ \\
\hline 16 & Fazekas & 62 & $\checkmark$ & $\checkmark$ & $\checkmark$ & $\checkmark$ \\
\hline 17 & Fürdő & 11 & $\checkmark$ & - & $\checkmark$ & $\sqrt{ }$ \\
\hline 18 & & 15 & - & - & $\checkmark$ & $\checkmark$ \\
\hline 19 & Hajdu & 38 & $\checkmark$ & - & $\checkmark$ & $\checkmark$ \\
\hline 20 & Hösök tér & 2 & $\checkmark$ & $\checkmark$ & $\checkmark$ & - \\
\hline 21 & Hosok ter & $9 / a$ & $\checkmark$ & $\checkmark$ & $\sqrt{ }$ & $\checkmark$ \\
\hline 22 & Kálvária-domb & - & $\checkmark$ & $\checkmark$ & $\checkmark$ & $\sqrt{ }$ \\
\hline 23 & Kálvária & 4 & $\checkmark$ & $\checkmark$ & - & $\checkmark$ \\
\hline 24 & & - & $\sqrt{ }$ & $\checkmark$ & $\checkmark$ & $\checkmark$ \\
\hline 25 & Kossuth tér & 6 & $\sqrt{ }$ & - & - & $\checkmark$ \\
\hline 26 & Kossum ter & 10 & $\checkmark$ & - & - & $\sqrt{ }$ \\
\hline 27 & & 15 & $\checkmark$ & - & $\checkmark$ & $\sqrt{ }$ \\
\hline 28 & & 7 & $\sqrt{ }$ & - & - & $\checkmark$ \\
\hline 29 & Rakocz1 & 11 & $\checkmark$ & - & $\checkmark$ & $\checkmark$ \\
\hline 30 & Tanoda tér & 5 & $\checkmark$ & $\checkmark$ & $\checkmark$ & - \\
\hline 31 & Tópart & 9 & $\sqrt{ }$ & $\checkmark$ & $\checkmark$ & - \\
\hline 32 & & - & $\sqrt{ }$ & $\checkmark$ & $\sqrt{ }$ & - \\
\hline 33 & Váralia & 2 & - & - & $\checkmark$ & $\checkmark$ \\
\hline 34 & valaja & 3 & - & - & $\checkmark$ & $\checkmark$ \\
\hline 35 & & 14 & - & - & $\checkmark$ & $\checkmark$ \\
\hline
\end{tabular}

\subsection{Index based archetype definition method}

For the quantitative analysis, the use of the in-plan indices from [9], [10] is proposed, together with two new coefficients that should help in the evaluation of the global adequacy of the surveyed buildings for archetype generation. The in-plan directional indices and formulas were applied to guide a simplified pre-analysis guiding intervention priority [10] and then vulnerability analysis of monumental buildings' databases [9], but never for archetype generation. They are based on in-plan areas of the walls, which are seismic resistant in the presence of a horizontal action. This is of particular relevance because they anticipate the seismic strength of the structure, which would be evident in the case of static pushover analysis of the buildings. 


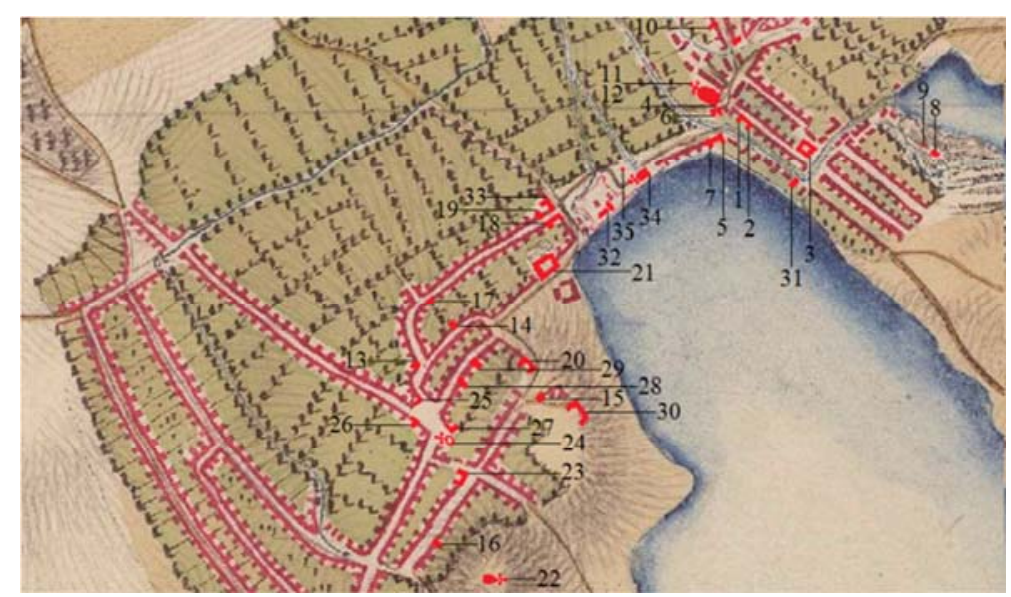

Fig. 6. Location of surveyed buildings in the First Military Map (1763-1787) [33]

The in-plan area ratio $\left(\gamma_{1}\right)$ is related to the base shear strength and it is the quotient between the in-plane area of the resistant walls $\left(A_{w, i}\right)$ and the total in-plane area $(S)$. The area-to-weight ratio $\left(\gamma_{2}\right)$ is given by the horizontal cross-section per unit of weight and it is the quotient between the in-plane area of the resistant walls $\left(A_{w, i}\right)$ and the quasipermanent vertical action $(G)$. The base shear ratio $\left(\gamma_{3}\right)$ provides the safety value with respect to shear and it is the quotient between the seismic action $\left(F_{E}=\beta \times G\right)$ and the shear strength of the structure $\left(V_{R d, \text { base }}=F_{R d}\right)$, being $\beta$ the equivalent seismic static coefficient. They are calculated as follows:

$$
\begin{aligned}
& \gamma_{1, i}=A_{w, i} / S=k_{1} \cdot A_{w, i} / A_{w, t o t}>0.10 \\
& \gamma_{2, i}=A_{w, i} / G=k_{2} \cdot A_{w, i} / A_{w, t o t}>1.20 \mathrm{~m}^{2} / \mathrm{MN} \\
& \gamma_{3, i}=F_{R d, i} / F_{E}=k_{3} \cdot A_{w, i} / A_{w, t o t}>1.00
\end{aligned}
$$

with $A_{w, t o t}=A_{w, x}+A_{w, y}, k_{1}=A_{w, t o t} / S, k_{2}=A_{w, t o t} / G$ and $k_{3}=\left[\tan \varphi+f_{v k 0} /(\gamma \times G)\right] / \beta$. The indices are expected to provide both a pre-evaluation of safety and bounds for archetypes generation.

Furthermore, two more indices are here suggested. While the adequacy ratio $\left(c_{1}\right)$ accounts for how much the target building has been modified, the target to current wall to plan area ratio $\left(c_{2}\right)$ represents the change in material use in the structure of the building. These indices can be calculated using the total wall area $(S)$ and the plan area defined by the outer walls $\left(A_{p}\right)$ for both the target time $\left(t=t_{i}\right)$ and the survey, or current time $\left(t=t_{f}\right)$, being $\Delta A_{p}=A_{p, t f}-A_{p, t i}$ and $\Delta S=S_{t f}-S_{t i}$ : 


$$
\begin{aligned}
& c_{1}=1-\sqrt{\left(\Delta S / S_{t_{f}}\right)^{2}+\left(\Delta A_{p} / A_{p, t_{f}}\right)^{2}}, \\
& c_{2}=\left(S / A_{p}\right)_{t=t_{i}} /\left(S / A_{p}\right)_{t=t_{s}}-1 .
\end{aligned}
$$

\subsection{Illustration of the method}

The index framework is applied to the Tata survey, as an example of the process. For this particular case, it is described for the dwelling house with the ID 2 in Ady Endre Street 11, Tata (Fig. 7), in the area of the former city of Tóváros. This building is a paradigmatic example of the application of the methodology because despite its significant modifications over the years, it maintained some of its earlier features, making it possible to identify the baroque walls.

From the L-shaped dwelling in Fig. 7, three intervention periods can be identified, leading to the conclusion that the probable $18^{\text {th }} \mathrm{c}$ wall was preserved in the N-W wing of the building. The existence of a division in the characteristically baroque mansard roof and ellipsoidal windows, in this wing (Fig. 7, cut view) also confirms this hypothesis.

Furthermore, the existence of vaulted spaces and a basement suggests that this is probably the oldest part of perhaps a three-cell house. Identified the early building, the table with the input values for the case study is presented.

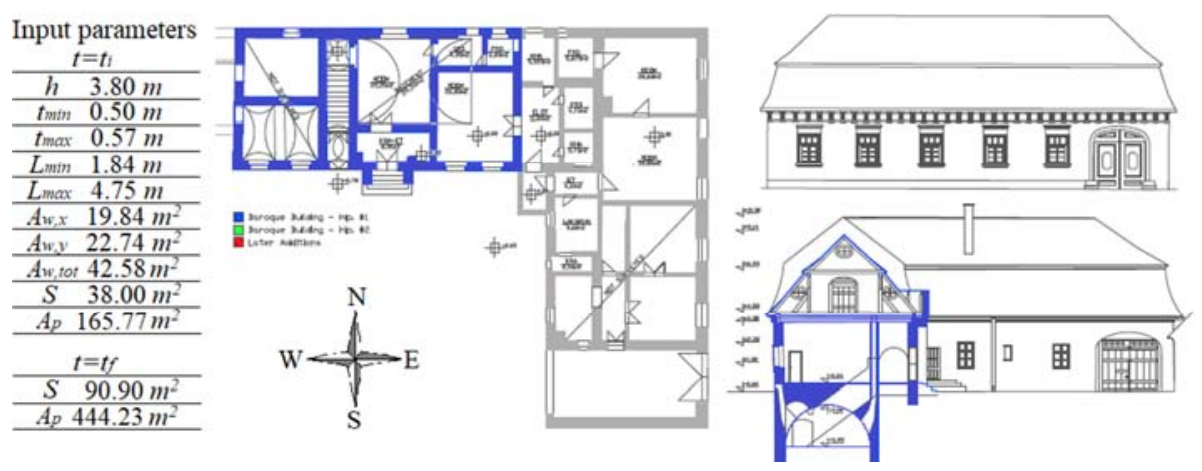

Fig. 7. Dwelling house of Ady Endre Street 11 [20] and geometric input parameters

Other inputs, material parameters as the density $\gamma=18 \mathrm{kN} / \mathrm{m}^{3}$, friction angle $\varphi=22^{\circ}$ cohesion $f_{v k 0}=0.10 \mathrm{MPa}$ and $\beta=1.00$ are assumed [9], [10]. Additional parameters are also necessary to attain the adequacy ratio. Thus, using the expressions (1)-(5) and the geometrical input parameters in Fig. 7, the in-plan indices $\left(\gamma_{i, d i r}\right)$ may be calculated, as can be seen in Table III.

The quantities as the total weight, $G=2945.75 \mathrm{kN}$, and the equivalent thickness, $t_{e q}=0.53 \mathrm{~m}$, which was verified to be in between the minimum and maximum thicknesses ( $t_{\min }$ and $t_{\max }$, Fig. 7). The adequacy ratio was estimated in $14.5 \%$ and the wall to plan area ratio shows an increase of $12 \%$ in material use in the walls. 
Table III

Output parameters and in-plan indices for the Ady Endre 11 dwelling and Archetype A0

\begin{tabular}{|c|c|c|c|c|c|c|c|c|c|}
\hline & \multicolumn{3}{|c|}{ Parameters } & \multicolumn{2}{c|}{$\begin{array}{c}\text { In-plan area } \\
\text { ratio }\end{array}$} & \multicolumn{2}{c|}{$\begin{array}{c}\text { Area to } \\
\text { weight ratio }\end{array}$} & \multicolumn{2}{c|}{$\begin{array}{c}\text { Base shear } \\
\text { ratio }\end{array}$} \\
\hline ID & $k_{1}$ & $k_{2}$ & $k_{3}$ & $\gamma_{1, x}$ & $\gamma_{1, y}$ & $\gamma_{2, x}$ & $\gamma_{2, y}$ & $\gamma_{3, x}$ & $\gamma_{3, y}$ \\
\hline 2 & 1.12 & 14.62 & 2.51 & 0.60 & 0.52 & 7.81 & 6.81 & 1.22 & 1.07 \\
A0 & 1.12 & 21.37 & 2.19 & 0.64 & 0.48 & 12.23 & 9.14 & 2.90 & 2.17 \\
\hline
\end{tabular}

Despite the identification of the building baroque part, deduced from the survey (Fig. 7, N-W wing), it is not yet an archetype, but the identification of a paradigmatic three cell house (A0, Fig. 8, right) enables its use to judge the previously assumed historical building archetype (section 2, Fig. 2, left), based on [13]. More archetypes are suggested elsewhere [35]. The in-plan ratios were calculated for the archetype (ID A0, Table III) aiming for comparison. An effect that this case is already an archetype results in the adequacy ratio and wall to plan area ratio being $c_{1}=c_{2}=0$, respectively. While the indices $\gamma_{1}$ show some similarity, the indices $\gamma_{2}$ and $\gamma_{3}$, are considerable discrepant, reaching differences of $45 \%$ and $63 \%$, respectively. This disparity can be explained by the difference in height $(3.80 \mathrm{~m}$ and $2.60 \mathrm{~m})$, affecting the self-weight. Thus, regarding the method, the archetype, in its actual state, cannot be considered representative of the presented dwelling, requiring a change in both the height and wall thickness values.

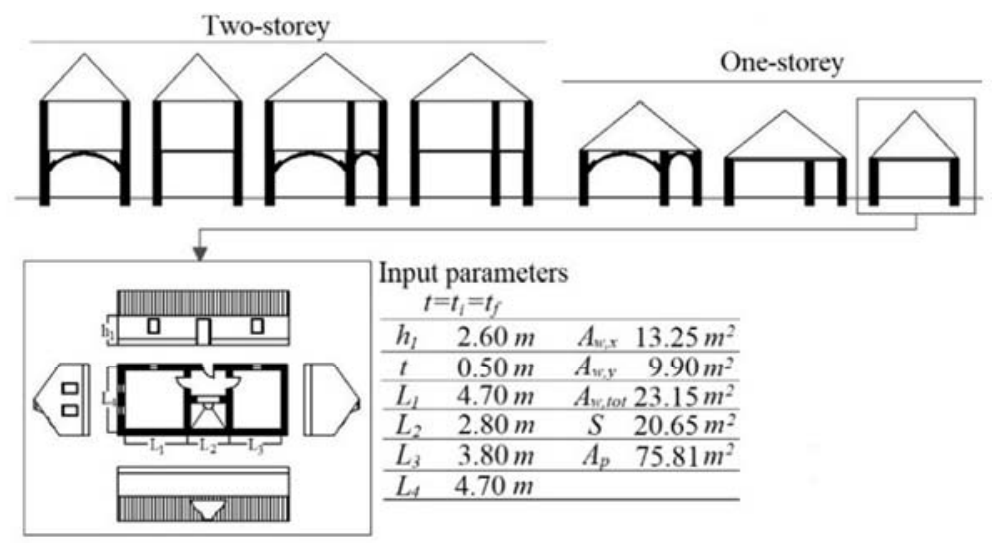

Fig. 8. One and two-storey cuts of building archetypes suggested in [13], and A0 input parameters

\section{Conclusion}

The present paper established the grounds for the development of an empirical and numerical framework for a method to generate region specific structural archetypes befitting seismic analysis. This approach uses in-plan safety indices that incorporate some of the regularities of the surveyed buildings. Two new indices were introduced in order to frame the adequacy and variation in material use. The generation of structural archetypes for CSM and DSA is an important step for the estimating of the magnitude 
of earthquakes using fragility functions and structural damage records. The application of the method to a previously assumed archetype resulted that the archetype mismatched the indexes of the surveyed dwelling, and although the exercise suggests grounds to modify the archetype towards bigger height and wall thickness. A broader composition and completeness of the framework would be required to elaborate broader conclusions.

The Tata historical survey is of considerable importance for it provides a broad empirical source for the generation of archetypes. Although, this study relies on a general historical survey together with historical plans. Therefore, limitations as missing geometry data, non-surveyed parts, and lack of information of the inner core of the structural elements, large variability of the mechanical properties, unknown exact construction sequence and possible joints could be overcome by using a true-to-form survey and by testing the mechanical properties in each surveyed building.

A full analysis of the historical damage records, regarding the magnitude estimation method is not yet done, as well as an estimation of the numbers and types of damaged structures in other cities of the region affected by the 1763 earthquake. Therefore, future developments should provide a full set of archetypes based on the evaluation of the historical damage sources, as well as the results of the DSA of the archetypes.

\section{Acknowledgements}

The Tata historical survey (1993) was supervised by Professors Gyula Istvánfi and Tamás Mezös and staff, for the subject of 'Monument Survey' created in the late 1970's by Professor Gyula Hajnóczi Institute of History and Theory of Architecture, Budapest University of Technology and Economics. Acknowledgements to CAPES (Process No. 9178-13-9). This paper was also supported by the János Bolyai Research Scholarship of the Hungarian Academy of Sciences.

\section{References}

[1] Vilimi A., Tóth L., Katona T. Analysis of consequences of a design basis earthquake for the region around a nuclear power plant, Pollack Periodica, Vol. 11, No. 2, 2016, pp. 43-54.

[2] Szeidovitz G. Earthquakes in the region of Komárom, Mór and Várpalota, Geophysical Translations, Vol. 32, No. 3, 1986, pp. 255-274.

[3] Szeidovitz G. Determination of epicentral intensity and focal depth of the earth-quakes occurred in the vicinity of Komárom and Mór (in Hungarian) CSc Thesis, Hungarian Academy of Sciences, Budapest, 1990.

[4] Ryu H., Kim J. K., Baker J. W. A probabilistic method for the magnitude estimation of a historical damaging earthquake using structural fragility functions, Bulletin of the Seismological Society of America, Vol. 99, No. 2A, 2009, pp. 520-537.

[5] Freeman S. A. The capacity spectrum method as a tool for seismic design, Proc. of 11th European Conf. on Earthquake Engineering, Paris, France, September 8, 1998, pp. 625.

[6] Vamvatsikos D., Cornell C. A. Incremental dynamic analysis, Earthquake Engineering and Structural Dynamics, Vol. 31, No. 3, 2002, pp. 491-514.

[7] Jalayer F., Cornell C. A. Alternative nonlinear demand estimation methods for probabilitybased seismic assessments, Earthquake Engineering and Structural Dynamics, Vol. 38, No. 8, 2009, pp. 951-972. 
[8] Istvánfi G. Surveys of settlements completed during the summer stages for students of architecture between 1980 and 1994, (in Hungarian) Budapest University of Technology and Economics, Institute of Theory and History of Architecture, Budapest, Hungary, 1995.

[9] Lourenço P. B., Oliveira D. V., Leite J. C., Ingham J. M., Modena C., da Porto F. Simplified indexes for the seismic assessment of masonry buildings: International database and validation, Engineering Failure Analysis, Vol. 34, 2013, pp. 585-605.

[10] Lourenço P. B., Roque J. A. Simplified indexes for the seismic vulnerability of ancient masonry buildings, Construction and Building Materials, Vol. 20, 2006, pp. 200-208.

[11] Eisinger U., Gutdeutsch R., Hammerl C. Historical earthquake research, an example of interdisciplinary cooperation between geophysicists and historians, Abhandlungen der Geologischen Bundesanstalt, Vol. 48, No. 1, 1992, pp. 33-50.

[12] Morais E. C., Vigh L. G., Krähling J. Preliminary estimation of the probable magnitude of Komárom 1763 earthquake using fragility functions, Proc. of 16th World Conference on Earthquake Engineering, Santiago, Chile, 9-13 January, 2017, www.researc hgate.net/profile/Eduardo_Jose_Morais, (last visited 25 January 2017).

[13] Morais E. C., Vigh L. G., Krähling J. Fragility estimation and comparison using IDA and simplified macro-modeling of in-plane shear in old masonry walls, Springer Proc. in Math. and Stat, Vol. 181, No. 1, 2016, pp. 277-291.

[14] Zsíros T. Seismicity of Komárom-Mór Area, Acta Geodaetica et Geophysica Hungarica,, Vol. 39, No. 1, 2003, pp. 121-131.

[15] Varga P., Szeidovitz G., Gutdeutsch R. Isoseismical map and tectonical position of the Komárom earthquake of 1763, Acta Geod. Geoph, Vol. 36, No. 1, 2000, pp. 97-108.

[16] Akkar S., Bommer J. J. Empirical equations for the prediction of PGA, PGV, and spectral accelerations in Europe, the Mediterranean Region, and the Middle East, Seismological Research Letters, Vol. 81, No. 2, 2010, pp. 195-206.

[17] Grossinger J. Dissertatio de terrae motibus regni Hungariae, Iaurini, Győr, 1783.

[18] Acta Terrae motus anni 1763, OL N-98. Ladula CCC Fascisculus A., No. 10, 1763.

[19] Réthly A. The earthquakes of the Carpathian Basins (455-1918) (in Hungarian), Akademiai Kiado, 1952.

[20] Tóth L., Győri E., Mónus P., Zsíros T. Seismic hazard in the Pannonian Region, In: N. Pintér (Ed.) The Adria Microplate, GPS Geodesy, Tectonics and Hazards, Netherlands, Springer, Vol. 61, No. 1, 2006, pp. 369-384.

[21] Zsíros T., Mónus P., Tóth L. Hungarian earthquake catalogue (456-1986), Geodetic \& Geophysical Research Institute, Budapest, 1998.

[22] Tóth L, Mónus P, Zsíros T, Kiszely M. Seismicity in the Pannonian Region, earthquake data, EGU Stephan Mueller Special Publication Series, Vol. 3, No. 1, 2002, pp. 9-28.

[23] AHEAD Working Group, AHEAD, the European Archive of Historical Earthquake Data. http://doi.org/10.6092/INGV.IT-AHEAD, (last visited 27 December 2016).

[24] Györi E., Tóth L., Mónus P. Secondary effects generated by earthquakes: liquefaction occurrences in and around Hungary, Acta Geod Geophys, Vol. 50, 2015, pp. 79-95.

[25] Labak P., Broucek I. Catalogue of macro-seismically observed earthquakes on the territory of Slovakia starting from the year 1034, Geoph. Inst. Slovak Acad. of Sci, Bratislava, 1995.

[26] Broucek I., Eisinger U., Farkas V., Gutdeutsch R., Hammerl C., Szeidovitz G. Reconstruction of building damage caused by the 1763 earthquake in Komárno/Danube from contemporary depictions of the same site and from respective texts, XXII General Assembly of ESC, Barcelona, Spain, 1990, pp. 353-363.

[27] Morais E. C., Vigh L. G., Krähling J. Global response evaluation of a Hungarian late Romanesque church due to a historical seismic event, Proc. 2nd Int. Conf. PhD Students in Civil Eng. and Arch, Cluj-Napoca, Romania, 2014, pp. 27-34.

[28] HAZUS-MH MR-1 Technical Manual, FEMA, Washington D.C, 2003. 
[29] Halmos B., Marótzy K. The adaptations of the true-to-form survey method, Periodica Polytechnica, Vol. 41, No. 1, 2010, pp. 9-17.

[30] Genthon I. Hungarian Monuments, (in Hungarian) Akademiai Kiado, Budapest, 1959.

[31] Rados J. Tata, Müszaki Könyvkiadó, 1964.

[32] Haris A. List of Hungarian Monuments, Komárom-Esztergom County, (in Hungarian) Kulturális Örökségvédelmi Hivatal, Budapest, 2006.

[33] Timár G., Biszak S., Székely B., Molnár G. Digitized maps of the Habsburg military surveys, Overview of the project of ARCANUM Ltd. (Hungary), In: Jobst M (Eds.), Preservation in digital cartography, Lecture Notes in Geoinformation and Cartography, Springer, Berlin-Heidelberg, 2011, pp. 273-283.

[34] Bereczki Z. The structural analysis of the (demolished) medieval system of St. Elisabeth's church in Kassa, Pollack Periodica, Vol. 9, No. 3, 2014, pp. 127-138.

[35] Morais E. C., Vigh L. G., Krähling J. Historical earthquakes and historical building archetypes for dynamic structural analysis using historical surveys, $3^{\text {rd }}$ International Conference on Protection of Historical Constructions, Lisbon, Portugal, 12-15 July 2017, www.researchgate.net/profile/Eduardo_Jose_Morais, (last visited 27 July 2017). 